\title{
HEPATOPROTECTIVE AND NEPHROPROTECTIVE EFFECTS OF THE AQUEOUS EXTRACT OF TURMERIC (CURCUMA LONGA) IN RIFAMPICIN AND ISONIAZID-INDUCED HEPATOTOXICITY AND NEPHROTOXICITY IN RATS
}

\author{
MAHDI M THUAWAINI ${ }^{1 *}$, MAWAHIB B GASIM AL-FARHAAN ${ }^{2}$, KARIMA F ABBAS ${ }^{3}$ \\ ${ }^{1}$ Department of Pathological Analysis, College of Health and Medical Sciences/Southern Technical University, Basrah, Iraq. \\ ${ }^{2,3}$ Department of Basic Sciences, College of Applied Medical Sciences, Karbala University, Karbala, Iraq. Email: Mahdi.Murshd@stu.ed.iq
}

Received: 15 November 2018, Revised and Accepted: 24 January 2019

\section{ABSTRACT}

Objectives: The present study was designed to estimate the influences of oral administration of aqueous extract of turmeric (Curcuma longa) in hepatotoxicity and nephrotoxicity induced in rats by isoniazid and rifampicin (RIF) for 4 weeks. Influences were determined through the estimation of liver and kidney functions and histopathological changes.

Materials and Methods: A total of 48 male albino rats were randomly divided into six groups: Normal control, INH+RIF treated rats, Turmeric aqueous extract $100 \mathrm{mg} / \mathrm{kg}$ treated rats, Turmeric aqueous extract $100 \mathrm{mg} / \mathrm{kg}+\mathrm{INH}$ and RIF treated rats, Turmeric aqueous extract $200 \mathrm{mg} / \mathrm{kg}$ treated rats, Turmeric aqueous extract $200 \mathrm{mg} / \mathrm{kg}+\mathrm{INH}$ and RIF treated rats. Turmeric aqueous extract and INH + RIF (50 mg/kg bwpo, daily) were given for 4 weeks. Liver and kidney function markers (aspartate transaminase [AST], alanine transaminase [ALT], alanine phosphatase [ALP], bilirubin, blood urea, and creatinine) were determined enzymatically. In addition, tissues of liver and kidney were quickly separated and fixed in $10 \%$ formalin and subjected to histopathological studies. Statistical analysis was carried out using t-test.

Results: The aqueous extract of turmeric (at a dose of 100 and $200 \mathrm{mg} / \mathrm{kg}$ bw, p.o. daily) showed hepato- and reno-protective effects in hepato- and reno- toxicity induced by RIF and INH in rats. Significant elevation of serum ALT, AST, ALP, total bilirubin, creatinine, urea, and total protein, due to RIF and INH treatment, were significantly decreased. The histopathological study further confirmed the biochemical results.

Conclusion: Results of the present study indicated that turmeric has hepatoprotective and renoprotective action against RIF- and INH-induced hepatic and renal injury in rats.

Keywords: Nephroprotective, Hepatoprotective, Turmeric (Curcuma longa), Biochemistry, Histopathology, Rifampicin, Isoniazid.

(c) 2019 The Authors. Published by Innovare Academic Sciences Pvt Ltd. This is an open access article under the CC BY license (http://creativecommons. org/licenses/by/4. 0/) DOI: http://dx.doi.org/10.22159/ajpcr.2019.v12i3.30419

\section{INTRODUCTION}

The metabolic processes of the human body are controlled and managed by two vital organs, the liver and kidney [1,2]. The liver and kidney actively metabolized numerous of drugs, hormones, and xenobiotics and maintain our systems. The liver is a main organ in the body and is responsible for the metabolism of internal and external agents. It plays a vital role in drug metabolism and detoxification. Liver injury may be caused by xenobiotic, alcohol consumption, malnutrition, infection, anemia, and medications [3]. Moreover, the liver is expected to be susceptible, especially to drugs and chemicals. Renal system is essential to maintain homeostasis, regulating water and electrolyte balance, and acidbase maintenance, among other crucial functions and also possessed an endocrine function [4]. However, the kidney is the well-known target of toxicity of therapeutic and environment xenobiotics, due to its high blood flow, tubular transport processes, and complex metabolic activities [5]. The drug-induced nephrotoxicity is manifested functionally by a decline in urine concentration, tubular proteinuria, lysosomal enzyme-urea, light glycosuria, sluggish ammonium excretion, and declining glomerular infiltration rate [2]; furthermore, drug-induced hepatic and nephritic injury is the most common cause for withdrawal of drugs.

However, antitubercular drugs, especially isoniazid and rifampicin (RIF)-induced hepatotoxicity, range from a non-specific elevation of transaminases to fulminant of liver failure. Furthermore, the incidence of hepatic dysfunction is more, when isoniazid (INH) and RIF are used in combination [9]. They were also induced renal toxicity [6-9].

Many medicinal plants showed hepato- and reno-protective effects [10-12], these included Agrimonia eupatoria [13], Alhagi maurorum [14], Allium sativum [15], Anchusa strigosa [16], Arctium lappa [17], Astragalus hamosus [18], Bauhinia variegata [19], Brassica nigra [20], Brassica rapa [21], Bryonia dioica [22], Bryophyllum calycinum [23], Caesalpinia crista [24], Calendula officinalis [25], Calotropis procera [26], Canna indica [27], Caparis spinosa [28], Capsella bursa-pastoris [29,30], Carthamus tinctorius [31], Carum carvi [32], Cassia occidentalis [33], Casuarina equisetifolia [34], Celosia cristata [35], Chenopodium album [36], Cicer arietinum [37], Cichorium intybus [38], Citrullus colocynthis [39], Citrus species [40], Clitoriaternatae [41], Convolvulus arvensis [42], Cordia myxa [43], Coriandrum sativum [44], Crocus sativus [45], Crotalaria juncea [46], Cuminum cyminum [47], Cupressus sempervirens [48], Curcuma longa [49], Cymbopogon schoenanthus [50], Cynodon dactylon [51], Cyperus rotundus [52], Daucus carota [53], Digitalis species [54], Dodonaea viscosa [55], Ephedra species [56], Equisetum arvense [57], Eupatorium cannabinum [58], Euphorbia hirta [59], Fumaria parviflora [60], Galium verum [61], Helianthus annuus [62], Hibiscus cannabinus [63], Hypericum triquetrifolium [64], Juniperus communis [65], and Jussiaea repens [66]. This study was designed to investigate the hepato- and reno-protective effects of turmeric (C. longa) in experimentally rifampin- and isoniazidinduced hepatotoxicity and nephrotoxicity in rats.

\section{MATERIALS AND METHODS}

Experimental animals

A total of 80 Wistar albino adult male rats (Rattus norvegicus), 150$250 \mathrm{~g}$, were used in this study. They were gained from the laboratory animal house, College of Science, Thi-Qar University. The animals were dwelled individually in well-ventilated polypropylene cage, in conditioned room [at temperature $\left(22 \pm 3^{\circ} \mathrm{C}\right)$, a 12 -h light/dark cycle 
and relative humidity were maintained in the room]. Diet and water were allowed ad libitum. At temperature $\left(22 \pm 3^{\circ} \mathrm{C}\right)$, a 12 -h light/dark cycle and relative humidity were maintained in the room.

\section{Chemicals and plant extract}

Kidney and liver function tests were evaluated using an enzymatic kit (Biomedicals Pvt. Ltd.). RIF and INH were purchased from Sigma Chemicals, and all other chemicals used for this study were of analytical grade. Fine crude ground turmeric (C. longa) was obtained from the local market of Basrah city, Iraq, and diagnosed by the plant herbarium of the College Of Science, Thi-Qar University.

\section{Experimental design}

A total of 48 male albino rats were randomly divided into 6 groups: Control, INH + RIF treatedturmeric $100 \mathrm{mg} / \mathrm{kg}$ without induction of hepato- and reno-toxicity, turmeric $100 \mathrm{mg} / \mathrm{kg}+\mathrm{RIF}$ and INH, turmeric $100 \mathrm{mg} / \mathrm{kg}$ without induction of hepato- and reno-toxicity, and turmeric $200 \mathrm{mg} / \mathrm{kg}+\mathrm{RIF}$ and INH. The turmeric aqueous extract and INH + RIF (50 mg/kg bw po, daily) were given for 4 weeks $[67,68]$

\section{Blood sampling and estimation of biochemical parameters}

About $24 \mathrm{~h}$ after the last doses of the treatments, the rats were anesthetized lightly by chloroform inhalation and then killed by neck dislocation, and then blood samples were collected by heart puncture; each sample was kept into non-heparinized tubes. The blood of nonheparinized tubes was abandoned at room temperature for $30 \mathrm{~min}$ and then was centrifuged at $3000 \mathrm{rpm}$ for $15 \mathrm{~min}$, and the sera were kept in deep freeze $\left(-20^{\circ} \mathrm{C}\right)$ until the biochemical examination [aspartate transaminase (AST), alanine transanase (ALT), alanine phosphatase (ALP), bilirubin, urea in the blood, creatine in the blood, Total protein] were performed.

\section{Histopathological assays}

Samples of liver and kidney were taken from the treated and control rats and were prepared for light microscopic study according to routine histological techniques.

\section{Statistical analysis}

Student t-test was used to determine the significance among the treated group in comparison with positive and negative controls [69].

\section{RESULTS}

\section{Biochemical investigation}

According to biochemical investigation, Group 3 treated by turmeric aqueous extract $100 \mathrm{mg} / \mathrm{kg}$ and Group 5 treated by turmeric aqueous extract $200 \mathrm{mg} / \mathrm{kg}$ for 28 days showed no significant changes compared with Group 1 (control group) in the serum levels of ALT, AST, ALP, and total bilirubin (Table 1) and serum creatinine, urea, and total protein (Table 2) which clearly indicate that both doses of turmeric aqueous extract are safe. However, in comparison with INH- and RIF-treated group (Group 2), both doses of turmeric aqueous extract significantly decreased the elevated serum levels of ALT, AST, ALP, and total bilirubin (Table 1) and serum creatinine, urea, and total protein (Table 2); however, the level of these biochemical parameters significantly stayed more than normal limits.

\section{Histological investigation}

The histopathological study revealed that the sections in the liver of rats from control group showed normal cellular architecture with distinguished hepatic cells, sinusoidal spaces, and central vein showing polyhedral hepatocytes and clear-cut hepatic structural architecture regulated in strands around the central vein (Fig. 1).

The livers of rats treated with INH and RIF showed massive, cellular necrosis, vacuolization, and ballooning degeneration displayed hard damage in the hepatic architecture. Most of the hepatocytes fused together forming eosinophilic syncytial masses, part of multiple areas, fine-bluish in color indicated calcifications. Furthermore, histological exam showed dilatation of hepatic sinusoid, severe degeneration of hepatocytes which appeared with huge vacuolated cytoplasm and inconspicuous cell outlines and the infiltration of inflammatory cells mostly around the portal vein (Fig. 2).

On the other hand, sections in livers of rats treated with INH and RIF and turmeric (C. longa) aqueous extract (100 and $200 \mathrm{mg} / \mathrm{kg}$ ) apparently showed regeneration and amelioration of hepatic cells around the central vein. Furthermore, displayed more or less architecture analogous to the control group where the cellular equalization around the central vein was restored. Similarly, it restored the blood vessels to normal condition (angiogenesis) and nearly brought back normal tissue with slight sinusoidal space expansion (Fig. 3).

Table 1: The effect of oral administration of turmeric aqueous extract 100 and $200 \mathrm{mg} / \mathrm{kg}$ on serum liver enzymes (ALT, AST, and ALP) and total bilirubin in IRF- and INH-induced hepatotoxicity in rats

\begin{tabular}{|c|c|c|c|c|c|}
\hline Groups & Groups description & S. ALT IU/L & S. AST IU/L & S. ALP IU/L & Total bilirubin mg/dl \\
\hline Group 1 & Normal control & $59.9 \pm 2.31^{\mathrm{a}}$ & $98.8 \pm 4.34^{\mathrm{a}}$ & $247.41 \pm 11.23^{\mathrm{a}}$ & $2.01 \pm 0.22^{\mathrm{a}}$ \\
\hline Group 2 & INH+RIF treated rats & $158.8 \pm 26^{b}$ & $124.44 \pm 11.23^{\mathrm{b}}$ & $399.30 \pm 30.4^{\mathrm{b}}$ & $4.06 \pm 0.51^{b}$ \\
\hline Group 3 & Turmeric aqueous extract $100 \mathrm{mg} / \mathrm{kg}$ treated rats & $62.7 \pm 3.34^{\mathrm{NS}}$ & $101 \pm 3.22^{\mathrm{NS}}$ & $234.14 \pm 6.34^{\mathrm{NS}}$ & $1.97 \pm 0.05^{\mathrm{NS}}$ \\
\hline Group 4 & Turmeric aqueous extract $100 \mathrm{mg} / \mathrm{kg}+\mid \mathrm{INH}$ and RIF treated rats & $138.2 \pm 4.98^{c}$ & $115.22 \pm 6.61^{\mathrm{c}}$ & $356.33 \pm 8.33^{c}$ & $2.82 \pm 0.04^{\mathrm{c}}$ \\
\hline Group 5 & Turmeric aqueous extract $200 \mathrm{mg} / \mathrm{kg}$ treated rats & $65.76 \pm 2.99^{\mathrm{NS}}$ & $109.34 \pm 8.44^{\mathrm{NS}}$ & $231.33 \pm 23.44^{\mathrm{NS}}$ & $2.30 \pm 0.17^{\mathrm{NS}}$ \\
\hline Group 6 & Turmeric aqueous extract $200 \mathrm{mg} / \mathrm{kg}+\mathrm{INH}$ and RIF treated rats & $131 \pm 2.26^{\mathrm{c}}$ & $99.21 \pm 53^{c}$ & $333.22 \pm 16.40^{c}$ & $2.42 \pm 0.28^{c}$ \\
\hline
\end{tabular}

All values expression by mean \pm SD, (n=8 in each group). Groups 2, 3, and 5 were compared with Group 1 (normal control) and Groups 4 and 6 were compared with Group 2: Different letters mean significant, NS: Not significant. SD: Standard deviation, AST: Aspartate transaminase, ALT: Alanine transaminase, ALP: Alanine phosphatase, RIF: Rifampicin, INH: Isoniazid

Table 2: The effect of oral administration of turmeric aqueous extract 100 and $200 \mathrm{mg} / \mathrm{kg}$ on serum urea, serum creatinine, and total protein levels in IRF- and INH-induced nephrotoxicity in rats

\begin{tabular}{|c|c|c|c|c|}
\hline $\begin{array}{l}\text { Treatment } \\
\text { groups }\end{array}$ & Groups description & Serum creatinine $\mathrm{mg} / \mathrm{dl}$ & Serum urea $\mathrm{g} / \mathrm{dl}$ & Total protein $\mathrm{g} / \mathrm{dl}$ \\
\hline Group 1 & Normal control & $1.92 \pm 0.06^{\mathrm{a}}$ & $3.73 \pm 0.36^{\mathrm{a}}$ & $7.76 \pm 0.18^{\mathrm{a}}$ \\
\hline Group 2 & INH+RIF treated rats & $3.19 \pm 0.02^{\mathrm{b}}$ & $4.68 \pm 0.56^{\mathrm{b}}$ & $6.08 \pm 0.12^{\mathrm{b}}$ \\
\hline Group 3 & Turmeric aqueous extract $100 \mathrm{mg} / \mathrm{kg}$ treated rats & $2.51 \pm 0.01^{\mathrm{NS}}$ & $3.98 \pm 0.08^{\mathrm{NS}}$ & $7.69 \pm 0.10^{\mathrm{NS}}$ \\
\hline Group 4 & Turmeric aqueous extract $100 \mathrm{mg} / \mathrm{kg}+\mid \mathrm{INH}$ and RIF treated rats & $2.22 \pm 0.09^{c}$ & $3.09 \pm 0.11^{\mathrm{c}}$ & $6.56 \pm 0.10^{c}$ \\
\hline Group 5 & Turmeric aqueous extract $200 \mathrm{mg} / \mathrm{kg}$ treated rats & $2.09 \pm 0.3^{\mathrm{NS}}$ & $3.49 \pm 0.85^{\mathrm{NS}}$ & $7.70 \pm 0.12^{\mathrm{NS}}$ \\
\hline Group 6 & Turmeric aqueous extract $200 \mathrm{mg} / \mathrm{kg}+\mathrm{INH}$ and RIF treated rats & $2.09 \pm 0.14^{c}$ & $3.51 \pm 1.28^{c}$ & $6.72 \pm 0.43^{c}$ \\
\hline
\end{tabular}

All values expression by mean \pm SD, (n=8 in each group), Group 2, 3 and 5 were compared with Group 1 (normal control) and Group 4 and 6 were compared with Group 2: Different letters mean significant, NS: Not significant. SD: Standard deviation, RIF: Rifampicin, INH: Isoniazid 


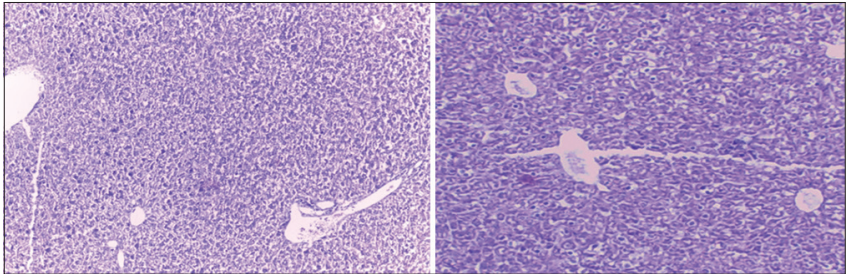

Fig. 1: Sections in the liver of rats from control group showed normal cellular architecture with distinguished hepatic cells, sinusoidal spaces and central vein, polyhedral hepatocytes, clearcut hepatic structural architecture regulated in strands around the central vein $(\mathrm{Hx}$ and $\mathrm{E}, \times 200)$

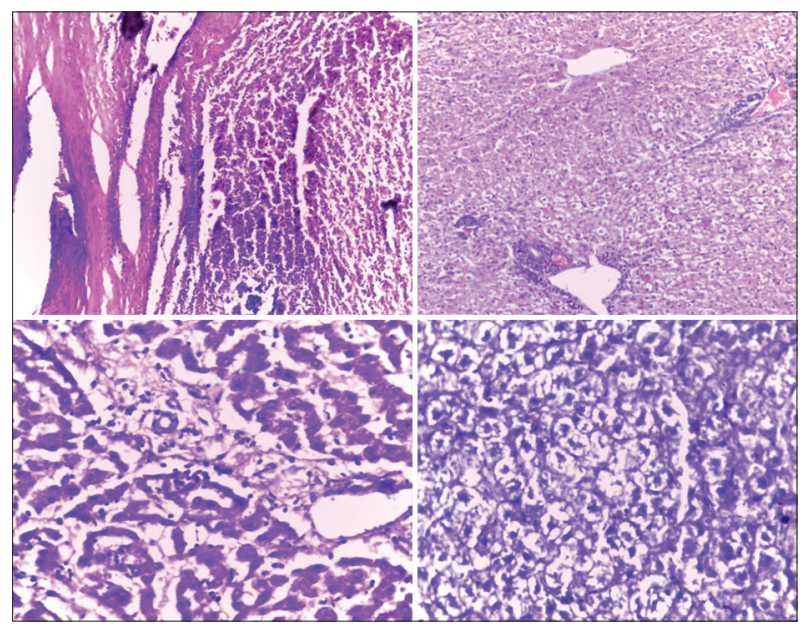

Fig. 2: Sections in the livers of rats treated with isoniazid and rifampicin (induction group) showing massive, cellular necrosis, vacuolization, and ballooning degeneration, displayed hard damage in the hepatic architecture. Most of the hepatocytes fused together forming eosinophilic syncytial masses, part of multiple areas, fine bluish in color indicated calcifications. Dilatation of blood sinusoid severe degeneration of hepatocytes, with huge vacuolation of hepatic cytoplasm and inconspicuous cell outlines also with infiltration of inflammatory cells around the portal venule ( $\mathrm{Hx}$ and $\mathrm{E}, \mathrm{x400})$
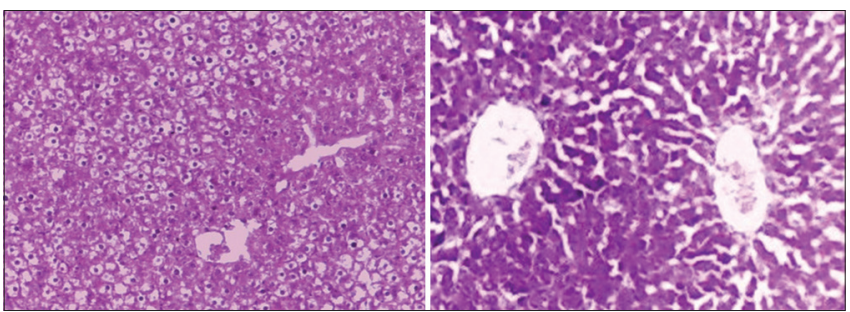

Fig. 3: Sections in the livers of rats treated with isoniazid and rifampicin and turmeric (Curcuma longa) aqueous extract [100 and $200 \mathrm{mg} / \mathrm{kg}$ ] showed apparent regeneration and amelioration of hepatic cells around the central vein and noted elaboration around the portal area. Furthermore, it displayed more or less architecture analogous to the control group where the cellular equalization around the central vein was restored. Likewise, it aided to get the blood vessels to normal condition (angiogenesis) noted with the control group and nearly restored normal tissue

with slight sinusoidal space expansion [Hx and E, 200X].

Some of the liver sections of rats treated with turmeric aqueous extract (100 and $200 \mathrm{mg} / \mathrm{kg}$ ) showed normal appearance of hepatocytes and central vein, hepatocytes appeared intact with slight dilatation of central

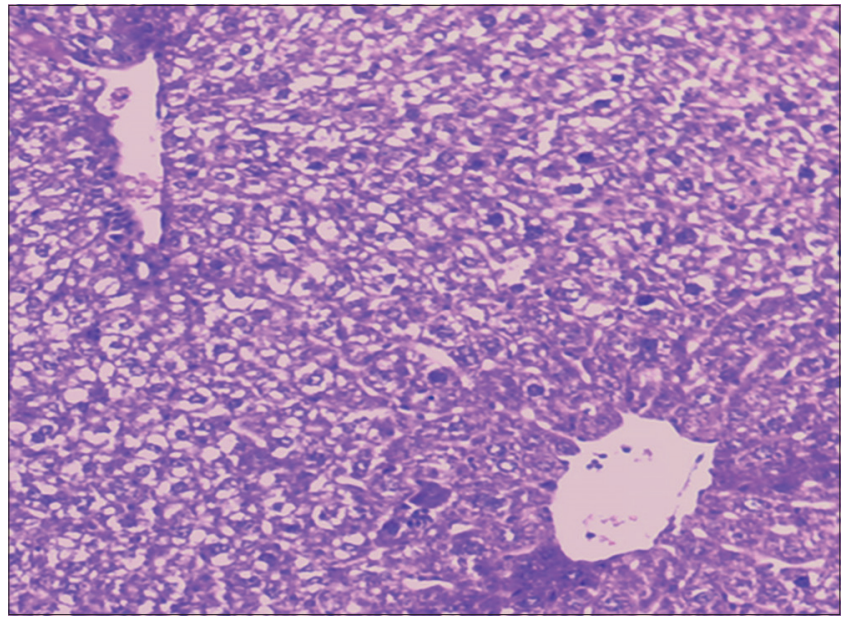

Fig. 4: Sections in livers of rats treated with turmeric (Curcuma longa) aqueous extract (100 and $200 \mathrm{mg} / \mathrm{kg}$ ) showing approximate brought back of normal appearance of hepatocytes and central vein. Hepatocytes appeared intact and slight dilatation of the central vein, the portal area showed a moderate infiltration of mononuclear leukocytes inflammatory cells compared to isoniazid and rifampicin treated rat. Normal condition (angiogenesis) as noted in the control group $(\mathrm{Hx}$ and $\mathrm{E}, \times 200)$

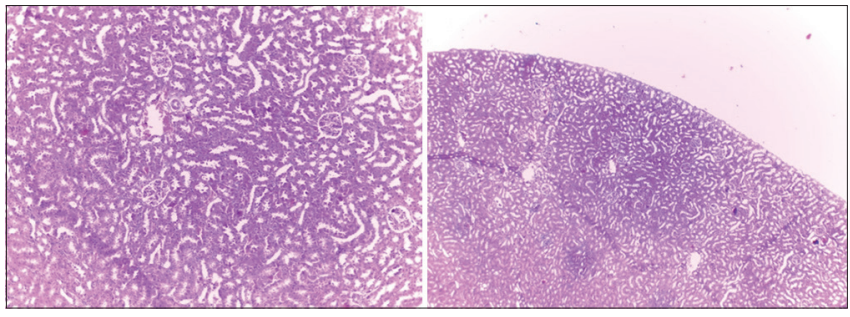

Fig. 5: Sections in the kidney of rats showed normal cellular architecture with distinguished renal cells $(\mathrm{Hx}$ and $\mathrm{E}, \times 200)$

vein, and the portal area showed moderate infiltration of mononuclear leukocytes inflammatory cells with normal angiogenesis (Fig. 4).

Conversely, examination of histopathological sections of kidneys revealed that the control group showed normal renal architecture characterized by normal glomerular and tubular histology, i.e., there were no observable changes in the kidney tissue morphology (Fig. 5).

Sections in the kidney of rats treated with INH and RIF showed severe changes evidenced by thickening and vacuolations in the wall of renal blood vessels, perivascular polymorphonuclear cells infiltration simultaneously evident renal casts, conspicuous vacuolations of the glomerular tufts joined and huge cellularity of the glomerulus tufts, areas of necrosis in renal tubular tissue and cell nuclei pyknosis, and focal of interstitial nephritis infiltrated areas with inflammatory cells mostly mononucleosiswith dilatation, edema, and inflammation of tubules (Fig. 6).

Sections in the kidney of rats treated with INH and RIF with turmeric (C. longa) aqueous extract (100 and $200 \mathrm{mg} / \mathrm{kg}$ ) significantly showed relieved severity of renal lesions and renal tubular injury, reduced dilation and inflammations of tubules as well as normal renal parenchyma with minimal congestion of blood vessels (Fig. 7).

Some sections in the kidney of rats treated with turmeric (C. longa) aqueous extract $(100$ and $200 \mathrm{mg} / \mathrm{kg}$ ) showed that tubule reveals slight degenerative change, almost normal appearance of glomeruli and tubules as a control group (Fig. 8). 


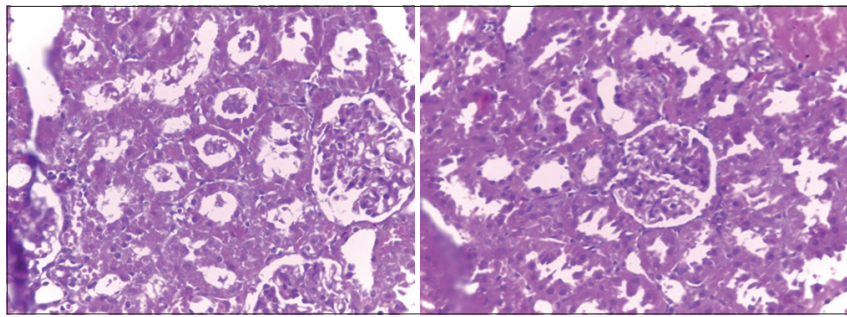

Fig. 6: Sections in the kidney of rats treated with isoniazid and rifampicin (induction group) showing histological changes as evidenced by thickening and vacuolations in the wall of renal blood vessels, perivascular polymorphonuclear cells infiltration simultaneously evident renal casts, conspicuous vacuolations of the glomerular tufts joined and huge cellularity of the glomerulus tufts, areas of necrotic renal tubular tissue and cell nuclei pyknosis, and focal of areas of interstitial nephritis infiltrated with inflammatory cells infiltration mostly mononucleosis. Dilatation ( $\mathrm{Hx}$ and $\mathrm{E}, \times 400)$

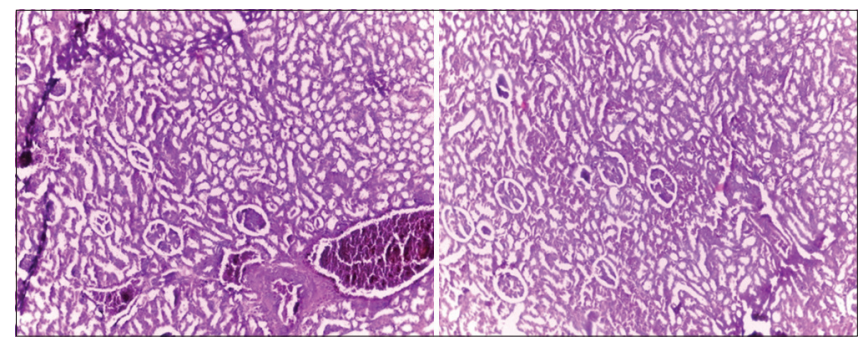

Fig. 7: Sections in the kidney of rats treated with isoniazid and rifampicin and turmeric (Curcuma longa) aqueous extract (100 and $200 \mathrm{mg} / \mathrm{kg}$ ) showed significantly relieved severity of renal lesions and renal tubular injury in addition to the reduction in dilation and inflammations of tubules $(\mathrm{Hx}$ and $\mathrm{E}, \times 200)$

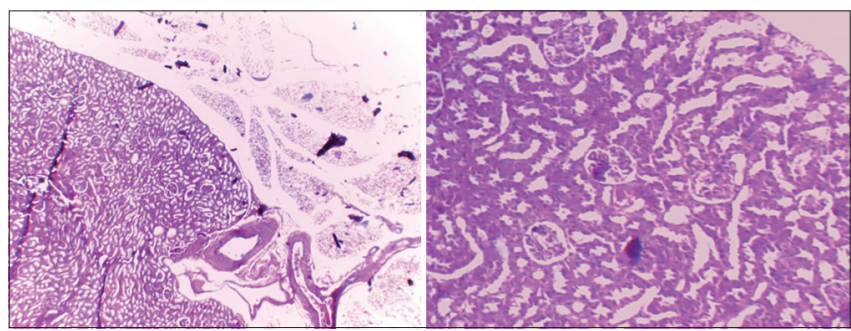

Fig. 8: Sections in the kidney of rats treated with turmeric (Curcuma longa) aqueous extract ( 100 and $200 \mathrm{mg} / \mathrm{kg}$ ) showing tubule with slight degenerative change, almost normal appearance of glomeruli and tubules

\section{DISCUSSION}

The present study was carried out to evaluate the effect of turmeric (C. longa) aqueous extracts on the renal and hepatic functions. INH and RIF which were used as anti-tuberculosis drugs (ATD) were not free from side effects [70]; it was associated with hepato- and reno-toxicity in some individuals [71].

Oxidative stress is the main attribution mechanism beyond ATDinduced hepato- and reno-toxicity [72]. Where, the hepatocytes membrane safety is lost as a result of lipid peroxides generation, due to oxidative stress in the cells [73]. However, the deleterious effect of INH and RIF drugs to the rat tissues was also noticed by elevated activities of enzymes (ALT, AST, and ALP) in the serum. The elevation of these enzymes in our study was matched with previous studies [74]. The elevation in the enzymatic activities of ALT, AST, and ALP can be considered as an important index for the diagnosis of liver diseases because these increases were attributed to increased lipid peroxidation, in such case, marked alterations in the molecular organization of lipids was occurred in the cellular membranes which increased membrane permeability and facilitated leakage of cytoplasmic markers into circulation [75].

In the previous studies, it was found that serum creatinine and serum urea were dramatically enhanced in INH- and RIF-treated animals [76,77]. Similarly, in the present study, the biochemical evaluation showed increased levels of serum creatinine and serum urea in the INH and RIF group compared with the control group. Elevation of serum creatinine and serum urea could be attributed to retention of ATD in nephrons causing severe injury [78].

Due to the involvement of oxidative stress in the mechanisms of renal and hepatic injury, the antioxidant properties of medicinal plants were involved in the mechanism of their hepatoprotective activity. They inhibited hepatic oxidative stress by many mechanisms. Curcumin, the major phenolic compound in turmeric, which shows preventive effects in various diseases, possessed antioxidant effects and inhibited extracellular matrix formation by enhancing matrix metalloproteinase expression through peroxisome proliferator-activated receptor gamma and by suppressing connective tissue growth factor expression $[79,80]$.

Many medicinal plants produced hepatoprotective effects through their anti-inflammatory activity and attenuation of many inflammatory processes [81].

Curcumin also induced downregulation of cyclooxygenase-2 expression which is involved in acute and chronic inflammation, hemodynamics, tumorigenesis, renal function, and hepatic fibrogenesis [82].

With regard to histopathological alterations in the rats treated with INH and RIF drugs (Group 2) or associated with the use of C. tinctorius extract with INH and RIF, were similar to the previous studies [83-86].

We can conclude that the hepatoprotection of the aqueous extract of C. tinctorius could be attributed to its antioxidant and anti-inflammatory effects.

\section{CONCLUSION}

The results of the present study indicate that turmeric has hepato- and reno-protective actions against RIF- and INH-induced hepatic and renal injury in rats.

\section{ETHICS APPROVAL}

The experimental work and uses of animals were performed according to Local Regulations of Animal House, Science College, Thi-Qar University.

\section{AUTHORS' CONTRIBUTIONS}

Mahdi M. Thuwaini (single author) drafted and approved the manuscript.

\section{CONFLICTS OF INTEREST}

The authors confirm that this paper's content has no conflict of interests.

\section{REFERENCES}

1. Josting D, Winne D, Bock KW. Glucuronidation of paracetamol, morphine and 1-naphthol in the rat intestinal loop. Biochem Pharmacol 1976;25:613-6.

2. Anders MW. Metabolism of drugs by the kidney. Kidney Int 1980;18:636-47.

3. Mroueh M, Saab Y, Rizkallah R. Hepatoprotective activity of Centaurium erythraea on acetaminophen-induced hepatotoxicity in rats. Phytother Res 2004;18:431-3.

4. Ligha AE, Jaja B, Numbere NF. Protective effect of Abrus precatorius 
seed extract following alcohol induced renal damage. Eur J Sci Res 2009;25:428-36.

5. Zhang JG, Lindup WE. Role of mitochondria in cisplatin-induced oxidative damage exhibited by rat renal cortical slices. Biochem Pharmacol 1993;45:2215-22

6. Ravi V, Patel SS, Verma NK, Dutta D, Saleem TS. Hepatotoxicity activity of Bombax ceiba Linn against isoniazid and rifampicin induced toxicity in experimental rats. Int J Appl Sci Res Nat Prod 2010;3:19-26.

7. Yue J, Peng RX, Yang J, Kong R, Liu J. CYP2E1 mediated isoniazidinduced hepatotoxicity in rats. Acta Pharmacol Sin 2004;25:699-704.

8. Tayal V, Kalra BS, Agarwal S, Khurana N, Gupta U. Hepatoprotective effect of tocopherol against isoniazid and rifampicin induced hepatotoxicity in albino rabbits. Indian J Exp Biol 2007;45:1031-6.

9. Jiang Y, Renxiu P, Jie C, Yinghui L and Guicheng D. Effect of rifampin on CYP2E1-dependent hepatotoxicity of isoniazid in rats. Pharm Res 2009;59:112-9.

10. Al-Snafi AE. Detoxification capacity and protective effects of medicinal plants [Part 2]: Plant based review. IOSR J Pharm 2016;6:63-84

11. Al-Snafi AE, Thwaini MM. Nephro- protective effects of Arabian medicinal plants [Part 1]. Res J Pharm Biol Chem Sci 2018;9:1504-11.

12. Al-Snafi AE, Thwaini MM. Arabian medicinal plants with hepatoprotective activity [Part 1]. Res J Pharm Biol Chem Sci 2018;9:1469-97.

13. Al-Snafi AE. The pharmacological and therapeutic importance of Agrimonia eupatoria- A review. Asian J Pharm Sci Technol 2015;5:112-7.

14. Al-Snafi AE. Alhagi maurorum as a potential medicinal herb: An overview. Int J Pharm Rev Res 2015;5:130-6.

15. Al-Snafi AE. Pharmacological effects of Allium species grown in Iraq. An overview. Int J Pharm Health Care Res2013;1:132-47.

16. Al-Snafi AE. The pharmacology of Anchusa italica and Anchusa strigosa - A review. Int J Pharm Pharm Sci 2014;6:7-10.

17. Al-Snafi AE. The pharmacological importance and chemical constituents of Arctium lappa. A review. Int J Pharm Res Schol 2014;3:663-70.

18. Al-Snafi AE. Chemical constituents and pharmacological effects of Astragalus hamosus and Astragalus tribuloides grown in Iraq. Asian J Pharm Sci Tech 2015;5:321-8.

19. Al-Snafi AE. The pharmacological importance of Bauhinia variegata. A review. Int J Pharm Sci Res 2013;4:160-4.

20. Rajamurugan R, Suyavaran A, Selvaganabathy N, Ramamurthy $\mathrm{CH}$, Reddy GP, Sujatha V, et al. Brassica nigra plays a remedy role in hepatic and renal damage. Pharm Biol 2012;50:1488-97.

21. Al-Snafi AE. The pharmacological importance of Brassica nigra and Brassica rapa grown in Iraq. J Pharm Biol 2015;5;240-53.

22. Al-Snafi AE. Therapeutic properties of medicinal plants: A review of their detoxification capacity and protective effects [Part 1]. Asian J Pharm Sci Technol 2015;5:257-70.

23. Al-Snafi AE. The chemical constituents and pharmacological effects of Bryophyllum calycinum. A review. J Pharm Sci Res 2013;4;171-6.

24. Al-Snafi AE. Pharmacology and medicinal properties of Caesalpinia crista - An overview. Int J Pharm 2015;5:71-83.

25. Al-Snafi AE. The chemical constituents and pharmacological effects of Calendula officinalis - A review. Indian J Pharm Sci Res 2015;5:172-85.

26. Al-Snafi AE. The constituents and pharmacological properties of Calotropis procera - An overview. Int J Pharm Rev Res 2015;5:259-75.

27. Al-Snafi AE. Bioactive components and pharmacological effects of Canna indica - An overview. Int J Pharm Toxicol 2015;5:71-5.

28. Al-Snafi AE. The chemical constituents and pharmacological effects of Capparis spinosa - An overview. Indian J Pharm Sci Res 2015;5:93-100.

29. Al-Snafi AE. The chemical constituents and pharmacological effects of Capsella bursa-pastoris - A review. Int J Pharm Toxicol 2015;5:76-81.

30. Al-Snafi AE. Encyclopedia of the Constituents and Pharmacological Effects of Iraqi Medicinal Plants. India: Rigi Publication; 2017.

31. Al-Snafi AE. The chemical constituents and pharmacological importance of Carthamus tinctorius - An overview. J Pharm Biol 2015;5:143-66.

32. Al-Snafi AE. The chemical constituents and pharmacological effects of Carum carvi - A review. Indian J Pharm Sci Res 2015;5:72-82.

33. Al-Snafi AE. The therapeutic importance of Cassia occidentalis - An overview. Indian J Pharm Sci Res 2015;5:158-71

34. Al-Snafi AE. The pharmacological importance of Casuarina equisetifolia - An overview. Indian J Pharm Screen Methods 2015;5:4-9.

35. Al-Snafi AE,the chemical constituents and pharmacological importance of Celosia cristata - A review. J of Pharm Biology 2015; 5[4]: 254-261.

36. Al-Snafi AE. The chemical constituents and pharmacological effects of Chenopodium album - An overview. Int J Pharm Screen Methods 2015;5:10-7.

37. Al-Snafi AE. The medical Importance of Cicer arietinum - A review. IOSR J Pharm 2016;6:29-40.
38. Al-Snafi AE. Medical importance of Cichorium intybus - A review. IOSR J Pharm 2016;6:41-56.

39. Al-snafi AE. Chemical constituents and pharmacological effects of Citrullus colocynthis - A review. IOSR J Pharm 2016;6:57-67.

40. Al-Snafi AE. Nutritional value and pharmacological importance of citrus species grown in Iraq. IOSR J Pharm 2016;6:76-108.

41. Al-Snafi AE. Pharmacological importance of Clitoria ternatea - A review. IOSR J Pharm 2016;6:68-83.

42. Al-Snafi AE. The chemical constituents and pharmacological effects of Convolvulus arvensis and Convolvulus scammonia - A review. IOSR J Pharm 2016;6:64-75

43. Al-Snafi AE. The pharmacological and therapeutic importance of Cordia myxa- A review. IOSR J Pharm 2016;6:47-57.

44. Al-Snafi AE. A review on chemical constituents and pharmacological activities of Coriandrum sativum. IOSR J Pharm 2016;6:17-42.

45. Al-Snafi AE. The pharmacology of Crocus sativus - A review. IOSR J Pharm 2016;6:8-38

46. Al-Snafi AE. The contents and pharmacology of Crotalaria juncea - A review. IOSR J Pharm 2016;6:77-86.

47. Al-Snafi AE. The pharmacological activities of Cuminum cyminum - A review. IOSR J Pharm 2016;6:46-65.

48. Al-Snafi AE. Medical importance of Cupressus sempervirens - A review. IOSR J Pharm 2016;6:66-76.

49. Thuwaini MM, Kadhem HS, Al-Dierawi KH. Nephroprotective activity of Matricaria chamomile and Curcuma longa aqueous extracts on tetracycline - Induced nephro-toxicity in albino rats. Int J Pharm Ther 2016;7:161-7.

50. Al-Snafi AE. The chemical constituents and pharmacological activities of Cymbopagon schoenanthus: A review. Chem Res J 2016;1:53-61.

51. Al-Snafi AE. Chemical constituents and pharmacological effects of Cynodon dactylon - A review. IOSR J Pharm 2016;6:17-31.

52. Al-Snafi AE. A review on Cyperus rotundus a potential medicinal plant. IOSR J Pharm 2016;6:32-48.

53. Al-Snafi AE. Nutritional and therapeutic importance of Daucus carota - A review. IOSR J Pharm 2017;7:72-88.

54. Al-Snafi AE. Phytochemical constituents and medicinal properties of Digitalis lanata and Digitalis purpurea - A review. Indo Am J P Sci 2017;4:225-34.

55. Al-Snafi AE. A review on Dodonaea viscosa: A potential medicinal plant. IOSR J Pharm 2017;7:10-21.

56. Al-Snafi AE. Therapeutic importance of Ephedra alata and Ephedra foliate - A review. Indo Am J P Sci 2017;4:399-406.

57. Al-Snafi AE. The pharmacology of Equisetum arvense - A review. IOSR J Pharm 2017; 7:31-42.

58. Al-Snafi AE. Chemical constituents, pharmacological and therapeutic effects of Eupatorium cannabinum - A review. Indo Am J Pharm Sci 2017:4:160-8.

59. Al-Snafi AE. Pharmacology and therapeutic potential of Euphorbia hirta [Syn: Euphorbia pilulifera] - A review. IOSR J Pharm 2017;7:7-20.

60. Al-Snafi AE. Fumaria parviflora - A review. Indo Am J Pharm Sci 2018;5:1728-38.

61. Al-Snafi AE. Galium verum - A review. Indo Am J Pharm Sci 2018:5:2142-9.

62. Al-Snafi AE. The pharmacological effects of Helianthus annuus - A review. Indo Am J Pharm Sci 2018:5:1745-56.

63. Al-Snafi AE. Pharmacological effects and therapeutic properties of Hibiscus cannabinus - A review. Indo Am J Pharm Sci 2018;5:2176-82.

64. Al-Snafi AE. Chemical constituents and pharmacological effects of Hypericum triquetrifolium. Indo Am J Phem Sci 2018;5:1757-65.

65. Al-Snafi AE. Medical importance of Juniperus communis - A review. Indo Am J Pharm Sci 2018;5:1979-92.

66. Al-Snafi AE. Constituents and pharmacological importance of Jussiaea repens - A review. Indo Am J Pharm Sci 2018;5:2206-12.

67. Satya V, Rana RP, Vaiphie K, Singh K. Effect of different oral doses of isoniazid-rifampicin in rats. Mol Cell Biochem 2006;289:39-47.

68. Fu Y, Zheng S, Lin J, Ryerse J, Chen A. Curcumin protects the rat liver from $\mathrm{CCl} 4$-caused injury and fibrogenesis by attenuating oxidative stress and suppressing inflammation. Mol Pharm 2008;73:399-409.

69. Brian SL, Everit S. A Handbook of Statistical Analyses Lesing SPSS. Florida: Chapman of Hell CRC; 2004.

70. Martin SJ, Sabina EP. Amelioration of anti-tuberculosis drug induced oxidative stress in kidneys by Spirulina fusiformis in a rat model. Ren Fail 2016;38:1115-21.

71. Sharma SK. Antituberculosis drugs and hepatotoxicity. Infect Genet Evol 2004;4:167-70.

72. Kale BP, Kothekar MA, Tayade HP, Jaju JB. Effect of aqueous extract of Azadirachta indica leaves on hepatotoxicity by antituberculosis 
drugs in rats. Indian J Pharm 2003;35:177-80

73. Jadhav VB, Thakare VN, Suralkar AA, Deshpande AD, Naik SR. Hepatoprotective activity of Luffa acutangula against $\mathrm{CCl} 4$ and rifampicin induced liver toxicity in rats: A biochemical and histopathological evaluation. Indian J Exp Biol 2010;48:822-9.

74. Shih TY, Young TH, Lee HS, Hsieh CB, Hu OY. Protective effects of kaempferol on isoniazid- and rifampicin-induced hepatotoxicity. AAPS J 2013; 15:753-62.

75. Thwaini MM, Kadhem HS. Hepatoprotective effects of simvastatin on paracetamol-induced hepatic damage in rats. IOSR J Pharm 2015;5:25-9.

76. Chang $\mathrm{CH}$, Chen $\mathrm{YF}, \mathrm{Wu}$ VC. Acute kidney injury due to antituberculosis drugs: A five-year experience in an aging population. BMC Infect Dis 2014;14:23.

77. Shaterpour M, Shaki F, Ghasemi M, Jafari-Sabet M, Ziar A, Ataee R. The protective effect of curcumin against lithium-induced nephrotoxicity in rats. Pharm Biomed Res 2017;3:33-8

78. Osawa T. Nephroprotective and hepatoprotective effects of curcuminoids. Adv Exp Med Biol 2007;595:407-23.

79. O’Connell MA, Rushworth SA. Curcumin: Potential for hepatic fibrosis therapy? Br J Pharmacol 2008;153:403-5.
80. Singh R, Sharma P. Hepatoprotective effect of curcumin on lindaneinduced oxidative stress in male Wistar rats. Toxicol Int 2011;18:124-9.

81. Wathoni N, Haerani A, Yuniarsih N, Haryantia R. Review on herbal cosmetics in indonesia. Int J Appl Pharm 2018;10:13-6.

82. Juasook A, Boonmars T, Wu Z, Loilome W, Veteewuthacharn K, Namwat $\mathrm{N}$, et al. Immunosuppressive prednisolone enhances early cholangiocarcinoma in Syrian hamsters with liver fluke infection and administration of N-nitrosodimethylamine. Pathol Oncol Res 2013;19:55-62.

83. Rady MI, Amany M. Histological alterations in the liver of mother rats and its weanlings fed on fried bread and the protective effect of curcumin. J Egypt Soc Toxicol 2006;35:19-25.

84. Muzika V, Čustović S, Mornjaković Z, Ćosović E, Kapić D. Histological study of isoniazid-rifampicin related nephrotoxicity in Wistar rats. Folia Med Fac Med Univ Saraeviensis 2016;51:4-9.

85. Kumar P, Roy I. Applications of gold nanoparticles in clinical medicine. Int J Pharm Pharm Sci 2016;8:9-16.

86. Furtado LM, Bundschuh M, Metcalfe CD. Monitoring the fate and transformation of silver nanoparticles in natural waters. Bull Environ Contam Toxicol 2016;97:449-55. 